\title{
DOPAD NEUTRALIZÁCIE PREPRAVNÝCH DOKUMENTOV NA ZODPOVEDNOSŤ CESTNÉHO DOPRAVCU
}

\section{IMPACT OF NEUTRALIZATION OF TRANSPORT DOCUMENTS ON THE RESPONSIBILITY OF THE ROAD CARRIER}

\author{
Miloš Poliak ${ }^{1, *}$, Jana Tomicová1
}

\begin{abstract}
Abstrakt
V roku 1956 bol prijatý významný dokument v oblasti cestnej nákladnej dopravy - Dohovor CMR. Jeho prijatím sa zjednotili niektoré pravidlá v medzinárodnej preprave tovarov. Zjednotila sa najmä sprievodná dokumentácia zásielky a zodpovednost' cestného dopravcu. Od prijatia Dohovoru CMR sa zmenil spôsob výpočtu zodpovednosti dopravcu, ktorý zaviedol Protokol k Dohovoru CMR. Protokol zmenil systém výpočtu zodpovednosti zo zlatého franku na systém založený na zvláštnych právach čerpania Sprievodná dokumentácia je zjednotená v cestnej nákladnej doprave v podobe nákladného listu CMR. Preukázalo sa, že neutralizácia nákladného listu sa v niektorých prípadoch využíva pri podvode na odosielatel'ovi. Ciel’om príspevku je zistit' dopad využívania neutralizácie nákladného listu na zodpovednost' dopravcu a postoj poist'ovne voči dopravcovi v prípade preukázania neutralizácie nákladného listu CMR. Z dôvodu, že prijatie Protokolu nie je samozrejmost'ou, existujú členské krajiny Dohovoru, ktoré Protokol neprijali. Vzhl'adom na to, že v súčasnosti teda existujú dva spôsoby ohraničenia zodpovednosti cestného dopravcu, chceme taktiež poukázat' na dôležitost' prijatia Protokolu k Dohovoru CMR a jeho vplyv na konkurencieschopnost' v prípade ak dopravcovi hrozí riziko z vykonania neutralizácie.
\end{abstract}

Klúčové slova nákladný list, Dohovor CMR, Protokol, zodpovednost', poistenie.

Summary In 1956, an important document in the field of road freight transport was adopted - the CMR Convention. Its adoption unified certain rules in the international carriage of goods. This unified in particular the accompanying documentation of the consignment and the liability of the road carrier. Since the adoption of the CMR Convention, the method of calculating the liability of the carrier, which has introduced the Protocol to the CMR Convention, has changed. The Protocol changed the system for calculating liability from a gold franc to a system based on special drawing rights. The accompanying documentation is unified in road freight transport in the form of a CMR consignment note. In recent years, carriers have been required to neutralize this accompanying document. It has been shown that neutralization of the consignment note is used in some cases for fraud on the consignor. The aim of the paper is to determine the impact of the use of neutralization of the CMR consignment note on the liability of the carrier and the attitude of the insurance company towards the carrier in case of proving the neutralization of the CMR consignment note. As the adoption of the Protocol is not a matter of course, there are the Member States of the Convention which have not accepted the Protocol. Given that there are currently two ways of limiting the liability of a road carrier, we also want to point out the importance of adopting the Protocol to the CMR Convention and its impact on competitiveness if the carrier is exposed to the risk of neutralization.

Keywords consignment note, CMR Convention, Protocol, liability, insurance

\footnotetext{
${ }^{1}$ Žilinská univerzita v Žiline, Fakulta prevádzky a ekonomiky dopravy a spojov, Katedra cestnej a mestskej dopravy, Univerzitná 8215/1, 01026 Žilina, Slovenská republika

*korespondenční autor, tel.: +421917924 876, e-mail: milos.poliak@fpedas.uniza.sk
} 


\section{1 ÚVOD}

Prepravovat' tovar v rámci medzinárodného obchodu je možne len na základe uzatvorenia prepravnej zmluvy. Uzatváranie prepravnej zmluvy pri medzinárodnej preprave upravuje Dohovor o prepravnej zmluve v medzinárodnej cestnej nákladnej doprave (Dohovor CMR). Tento dohovor je vel'mi dôležitým aspektom pre dopravcov pri uzatváraní prepravných zmlúv, pretože zjednodušuje prácu dopravcom, jednotne upravuje sprievodnú dokumentáciu prepravy tovaru, stanovuje zodpovednost' dopravcu a vytvára postupy, ktoré je možné použit' v prípade ak prepravcovi vznikne škoda. Neskôr bol k Dohovoru prijatý Protokol dôsledkom čoho sa zmenil spôsob a jednotka ohraničenia zodpovednosti cestného dopravcu. V súčasnosti všetky krajiny EU sú členskými krajinami Protokolu, okrem Bulharska.

Neodmyslitel'nou súčast'ou Dohovoru CMR je jeho nákladný list, ktorý predstavuje najdôležitejší doklad pri preprave. Je to doklad o uzatvorení prepravnej zmluvy a zároveň je dokladom o prevzatí zásielky dopravcom (Quigley, 2006). V posledných rokov sa v odvetví dopravy často vyžaduje od dopravcu aby vykonal neutralizáciu nákladného listu CMR. Pod pojmom neutralizácia sa rozumie výmena originálnych nákladných listov alebo prepravných dokladov inými nákladnými listami alebo prepravnými dokladmi. Ide o zrušenie účinku platnosti prvého nákladného listu, pričom počas celej prepravnej trasy z miesta fyzickej nakládky na miesto fyzickej vykládky nie je $s$ tovarom manipulované. Dochádza iba $\mathrm{k}$ vyhotovovaniu viacerých nákladných listov na jedno premiestnenie tovaru. Počas prepravy dochádza $\mathrm{k}$ umelému prerušovaniu prepravy z dôvodu odoberania pôvodných prepravných dokladov a vyrábania, výmeny nových prepravných dokladov (Mukherjee a Zhao, 2012). Zmyslom neutralizácie nákladného listu by malo byt' zabezpečenie obchodného tajomstva, kde predajca chce zabránit' tomu aby príjemca poznal výrobcu a jeho nákupné podmienky (Ahmadi a Yang, 2000; Ahmadi et al., 2017). Z výskumu „Poliak et al.,(2019) vyplýva, že pri neutralizácii prepravných dokladov taktiež môže dochádzat' k porušovaniu právneho poriadku v Slovenskej republike zo strany predajcu, presnejšie k porušeniu zákona č. 300/2005 Z.z. Trestný zákon - porušenie paragrafov: § 213 Sprenevera, § 221 Podvod, § 259 Skresl'ovanie údajov hospodárskej a obchodnej evidencie a $§ 375$ Poškodzovanie cudzích práv“. Z uvedeného dôvodu, je potrebné zaoberat' sa otázkou, či neutralizácia nákladného listu predstavuje riziko aj pre dopravcu. Konkrétne v tomto článku chceme preskúmat' dopad neutralizácie na zodpovednost’ dopravcu (poistenie zodpovednosti) v prípade poškodenia alebo zničenia tovaru, ak sa preukáže že bol vykonaný podvod na zákazníkovi. Ciel’om je teda overit' hypotézu, či neutralizácia prepravných dokumentov môže predstavovat' v takomto prípade riziko pre dopravcu. Vzhl'adom na to, že v súčasnosti existujú dva spôsoby ohraničenia zodpovednosti cestného dopravcu, chceme taktiež poukázat' na dôležitost' prijatia Protokolu k Dohovoru CMR a jeho vplyv na konkurencieschopnost' v prípade ak dopravcovi hrozí riziko z vykonania neutralizácie. Z hl'adiska problematiky je potrebné zamerat' sa na Dohovor CMR. Je to z toho dôvodu, že tento dohovor sa vzt'ahuje na každú zmluvu o preprave zásielok kde dokladom o uzavretí prepravnej zmluvy je nákladný list CMR. Pri neutralizácii prepravných dokladov dochádza práve k výmene nákladného listu CMR.

\section{ANALÝZA SÚČASNÉHO STAVU}

$\mathrm{Z}$ dôvodu rozdielnosti právnych predpisov $\mathrm{v}$ jednotlivých krajinách vo vzt'ahu k prepravnej zmluve bol prerokovaný na úrovni Európskej hospodárskej komisie OSN a v roku 1956 v Ženeve Rakúskom, Belgickom, Spolkovou republikou Nemecka, Francúzskom, Juhosláviou, Luxemburskom, Holandskom, Pol'skom, Švédskom a Švajčiarskom podpísaný Dohovor CMR. Pri tvorbe sa okrem národných vlád 10 štátov podiel'ali aj d’alšie nevládne organizácie a to Medzinárodná únia cestnej dopravy (IRU) v Ženeve a Medzinárodná obchodná komora (ICC) v Paríži. Pri formulácii Dohovoru CMR sa kládol dôraz najmä na to, aby bola jednotne upravená sprievodná dokumentácia prepravy tovaru, zásady zodpovednosti dopravcu a postup pri uplatňovaní náhrady škody. Dohovor upravuje aj pravidlá, práva, povinnosti dopravcu a prepravcu pri preprave tovaru. Je však potrebné spomenút', že Dohovor CMR neupravuje všetky súkromnoprávne otázky, s ktorými je možné sa stretnút' pri prepravách tovaru cestnými vozidlami 
(Verheyen, 2016) V priebehu svojej platnosti bol Dohovor CMR doplnený v roku 1978 o Protokol k Dohovoru CMR a v roku 2008 o Dodatkový protokol. V tabul'ke 1 sú uvedené členské krajiny Dohovoru CMR, Protokolu a Dodatkového protokolu.

Tab. 1 Rozdelenie členských krajín Dohovoru CMR; Zdroj: vlastné spracovanie

\begin{tabular}{cccc}
\hline $\begin{array}{c}\text { Členské krajiny } \\
\text { Dohovoru CMR, } \\
\text { Protokolu a }\end{array}$ & $\begin{array}{c}\text { Členské krajiny } \\
\text { Dohovoru CMR a } \\
\text { Protokolu }\end{array}$ & $\begin{array}{c}\text { Členské krajiny len } \\
\text { Dohovoru CMR }\end{array}$ & $\begin{array}{c}\text { Členské krajiny } \\
\text { Dohovoru a } \\
\text { Dodatkového } \\
\text { protokolu }\end{array}$ \\
\hline Bielorusko & Albánsko & Azerbajdžan & Tadžikistan \\
Belgicko & Arménsko & Bosna a Hercegovina & \\
Česká republika & Rakúsko & Bulharsko & \\
Dánsko & Chorvátsko & Kazachstan & \\
Estónsko & Cyprus & Mongolsko & \\
Fínsko & Georgia & Čierna Hora & \\
Francúzsko & Nemecko & Maroko & \\
Lotyšsko & Grécko & Srbsko & \\
Litva & Mad'arsko & Sýria & \\
Luxembursko & Irán & Ukrajina & \\
Holandsko & Írsko & & \\
Nórsko & Taliansko & & \\
Pol'sko & Jordánsko & & \\
Portugalsko & Kirgizsko & & \\
Moldavská republika & Libanon & & \\
Rumunsko & Malta & & \\
Ruská federácia & Severná Macedónsko & \\
Slovensko & Tunisko & \\
Slovinsko & Turecko & & \\
Španielsko & Turkménsko & & \\
Švédsko & Uzbekistan & & \\
Śvajčiarsko & & & \\
Spojené král'ovstvo & & & \\
Vel'kej Británie a & & & \\
Severného Írska & & & \\
\hline
\end{tabular}

Dohovor CMR sa vzt'ahuje na každú zmluvu o preprave zásielok za odplatu vykonanú cestným vozidlom, ak miesto prevzatia zásielky a aj predpokladané miesto jej dodania, ako sa uvádzajú v zmluve, ležia v dvoch rôznych štátoch, z ktorých aspoň jeden je zmluvným štátom Dohovoru CMR, bez ohl'adu na trvalé bydlisko a štátnu príslušnost' strán. Dohovor neupravuje medzinárodnú cestnú nákladnú dopravu ale iba náležitosti súvisiace s prepravnou zmluvou $v$ medzinárodnej cestnej nákladnej doprave, pričom sú povinné pri prepravách v prípade, ked' aspoň jeden štát (odoslania alebo prijatia) je členským štátom Dohovoru CMR. Existujú štáty napr. Česká republika, kde sa Dohovor CMR vzt’ahuje aj na vnútroštátnu prepravu. V Slovenskej republike dopravca môže použit' nákladný list CMR na vnútroštátnu prepravu, ale ustanovenia samotného Dohovoru CMR nie je možné na ňu uplatnit'.

Podl'a Dohovoru CMR sa preprava tovaru musí uskutočnit’ po ceste „pomocou vozidiel“, a preto zásielka musí byt' naložená na vozidle. Preto tento dohovor nie je možné uplatnit' pri preprave vozidiel na vlastných kolesách. Ďalej existujú aj tri výnimky, kde nie je možné uzatvorit’ prepravu podl'a Dohovoru CMR aj napriek tomu, že ide o medzinárodnú prepravu. Dohovor sa nevzt’ahuje na prepravu poštových zásielok, mŕtvych osôb a st'ahovavých zvrškov. Hlavným dôvodom, prečo nie je možné uvedené zásielky 
prepravovat' na základe Dohovoru CMR je skutočnost', že pri týchto zásielkach nie je možné objektívne bez znaleckého odhadu stanovit' hodnotu zásielky a tým identifikovat' zodpovednost' dopravcu pri preprave (Lamont-Black, 2016).

Dohovor postupne ratifikovali jednotlivé európske krajiny, ale zmluvnými členmi sú aj mimoeurópske krajiny. V súčasnosti Dohovor CMR podpísalo 56 krajín. Všetky krajiny EÚ sú zmluvnými stranami tohto Dohovoru. Jednotlivé členské krajiny sú uvedené na obr. 1. a v tabul'ke 1. Pakistan je momentálne posledná krajina, ktorá pristúpila k Dohovoru CMR k 30. máju 2019.

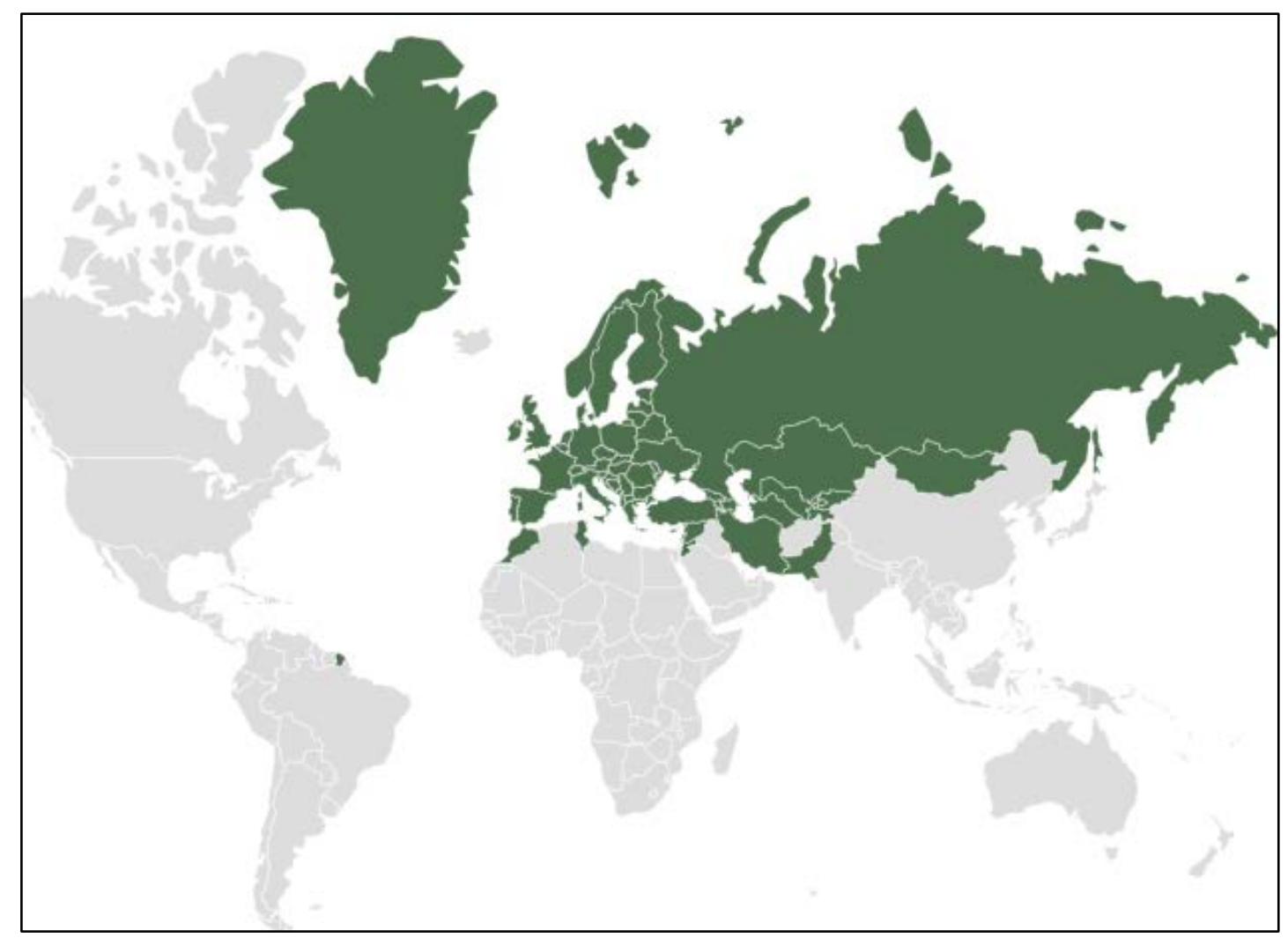

Obr. 1 Členské krajiny Dohovoru CMR; Zdroj: United Nations Treaty Collection

\subsection{Dokument potvrdzujúci existenciu prepravnej zmluvy}

Dokladom o uzatvorení prepravnej zmluvy je nákladný list. Ak však nákladný list chýba, alebo ak má nedostatky alebo sa stratil, nie je tým existencia alebo platnost' prepravnej zmluvy dotknutá a nad'alej sa na ňu vzt'ahujú ustanovenia Dohovoru. Nákladný list sa vystavuje v troch pôvodných vyhotoveniach, ktoré sú podpísané odosielatel'om a dopravcom. Tieto podpisy môžu byt' vytlačené alebo nahradené pečiatkami odosielatel'a a dopravcu, ak to dovol'uje právny poriadok štátu, v ktorom sa nákladný list vyhotovuje (Denes, 2018).

Nákladný list CMR sa skladá z minimálne 5 listov, musia byt' podpísané dopravcom a odosielatel’om, sú farebne odlíšené a sú určené:

- červený list - ostáva odosielatel’ovi ako doklad o tom, že dopravca prevzal zásielku (ak v kolónke č. 18 nie je nijaká výhrada dopravcu alebo vodiča),

- modrý list - určený pre príjemcu tovaru, príjemcovi sa odovzdáva po potvrdení všetkých zvyšných listov, na ktorých potvrdzuje prevzatie zásielky,

- zelený list - ostáva dopravcovi ako doklad o uskutočnenej preprave,

- 2 x čierny list - priloží sa $\mathrm{k}$ faktúre ako doklad o uskutočnení prepravy. Druhý čierny list vodič ponecháva colným orgánom pri príchode vozidla z jedného do druhého colného režimu. 
V Dohovore CMR nie je stanovená osoba, ktorá má vypĺňat' nákladný list. V praxi vo väčšine prípadov vypÍňa NL odosielatel' alebo zasielatel', prípadne dopravca (vodič) podl'a údajov poskytnutých odosielatel'om. Dopravca musí odosielatel'ovi poskytnút' formuláre nákladného listu. Údaje, ktoré sa musia nachádzat' v každom nákladnom liste:

- miesto a dátum vystavenia,

- meno a adresa odosielatel'a,

- meno a adresa dopravcu,

- miesto a dátum prevzatia zásielky a miesto jej určenia,

- meno a adresa príjemcu,

- obvyklé pomenovanie povahy prepravovanej veci a druh obalu; pri veciach nebezpečnej povahy ich všeobecne uznávané označenie,

- počet kusov, ich zvláštne značky a čísla,

- hrubá váha zásielky alebo iným spôsobom vyjadrené množstvo tovaru,

- náklady spojené s prepravou (dovozné, vedl’ajšie poplatky, clá a ostatné výdavky vznikajúce od okamihu uzavretia zmluvy až do vydania zásielky),

- pokyny potrebné pre colné a iné úradné konania,

- údaj o tom, že preprava aj napriek akejkolvek opačnej doložke podlieha ustanoveniam tohto Dohovoru.

Do nákladného listu môžu byt' zapísané aj iné údaje, ktoré zmluvné strany považujú za potrebné. V nákladnom liste CMR je vhodné uvádzat' aj evidenčné číslo t’ahača a návesu, aj ked' to nepatrí medzi povinný udaj. Je to z dôvodu platnosti poistnej zmluvy dopravcu. Ak sa evidenčné číslo vozidla, ktoré je uvedené v NL CMR nezhoduje s evidenčným číslom, ktoré je uvedené v poistnej zmluve dopravcu, v takomto prípade nie je možné vyplatit’ škodu dopravcovi.

Nákladný list je, pokial' sa nedokáže opak, vierohodným dokladom o uzavretí a obsahu prepravnej zmluvy, ako aj o prevzatí zásielky dopravcom. Ak nákladný list neobsahuje výhrady dopravcu s ich odôvodnením, platí právna domnienka, že zásielka a jej obal boli v okamihu prevzatia dopravcom v dobrom zjavnom stave a že počet kusov, ich značky a čísla sa zhodovali s údajmi v nákladnom liste (Bonnet, 2016).

V roku 2008 bol k Dohovoru o prepravnej zmluve v medzinárodnej cestnej nákladnej doprave prijatí Dodatkový protokol, ktorý požadoval, aby sa prepravné dokumenty CMR mohli spravovat' aj elektronicky prostredníctvom elektronického nákladného listu, tzv. „e-CMR“. Do 9.3.2020 k tomuto protokolu pristúpilo 25 krajín. V súčasnosti sa e-CMR využíva menej ako papierový. Je to z toho dôvodu, že jeho vel'kou nevýhodou je obmedzený geografický rozsah pôsobnosti. Medzinárodná preprava v rámci systému e-CMR je možná medzi dvoma signatárskymi krajinami iba vtedy, ak sa preprava neuskutočňuje cez krajiny, ktoré nie sú členskými krajinami Dodatkového protokolu. Ak dopravca prejde cez takúto krajinu, musí mat’ vypísaný papierový nákladný list vo vozidle.

\section{ZODPOVEDNOSŤ CESTNÉHO DOPRAVCU}

Jednou z najväčších výhod existencie Dohovoru CMR je jednotné ustanovenie ohraničujúce zodpovednost' dopravcu v prípade, že preprava podlieha ustanoveniam Dohovoru CMR. Zodpovednost' dopravcu začína v momente, ked' prevezme tovar na prepravu a končí v momente vydania tovaru príjemcovi. Pri prevzatí zásielky na prepravu dopravca by mal preskúmat':

a) správnost' údajov v nákladnom liste o počte kusov a o ich značkách a číslach, 
b) zjavný stav zásielky a jej obalu.

Dopravca zodpovedá za poškodenie alebo stratu zásielky počas prepravy a tiež za prekročenie dodacej lehoty. Oprávnený môže zásielku bez d’alších dôkazov považovat' za stratenú, ak zásielka nebola vydaná do 30 dní po uplynutí dojednanej lehoty, a pokial' nebola stanovená lehota, tak do 60 dní po prevzatí zásielky dopravcom na prepravu. Dopravca podl'a ustanovení Dohovoru CMR je povinný nahradit’ škodu za úplnú alebo čiastočnú stratu zásielky, ktorá vznikne od okamihu jej prevzatia k preprave až do okamihu jej vydania. Náhrada sa vypočíta z hodnoty zásielky v mieste a čase jej prevzatia na prepravu. Hodnota zásielky sa určuje podl'a burzovej ceny, ak nie je burzová cena, podl'a bežnej trhovej ceny, a ak nie je ani burzová ani bežná trhová cena, podl'a všeobecnej hodnoty tovaru rovnakej povahy a kvality.

Dopravca je oslobodený od zodpovednosti, ak stratu zásielky, jej poškodenie alebo prekročenie dodacej lehoty zavinil oprávnený, príkaz oprávneného, nebol zavinený nedbalost’ou dopravcu, vlastnou chybou zásielky alebo okolnost'ami, ktoré dopravca nemôže odvrátit' a ktorých následky odstránit' nie je v jeho moci (Lorenc a Kuznar, 2018). Zodpovednost' dopravcu v medzinárodnej cestnej nákladnej doprave je podl'a článku 23 odsek 3 Dohovoru CMR upravená tak, že náhrada škody nesmie presahovat' 25 frankov za kilogram chýbajúcej hrubej hmotnosti, pričom frankom sa rozumie zlatý frank hmotnosti 10/31gramu a rýdzosti 0,900 . Ak teda $\mathrm{v}$ rámci prepravy dôjde $\mathrm{k}$ poškodeniu alebo ku strate zásielky, dopravca zodpovedá za škody maximálne do výšky 25 frankov za každý poškodený alebo stratený kilogram zásielky (Sker , 2003). Tento systém obmedzenia zodpovednosti súvisí s určitou hodnotou zlata. Datuje sa od doby Bretton Woods Agreement, kedy svetový finančný systém sa spoliehal na stabilnú cenu zlata napriek kolísaniu meny vyjadrenú deklarovanou oficiálnou paritou zlata členmi Medzinárodného menového fondu (IMF). Bretton Woods Agreement sa zrušila v roku 1971 a meny už nemali pevný výmenný kurz v zlate a zlato sa začalo vol'ne kolísat' na trhoch. Odvtedy existovali dve hodnoty zlata: umelá oficiálna sadzba a sadzba vol'ného trhu, ktorá bola výrazne vyššia ako oficiálna a neustále kolísala. Dohovor CMR neposkytol riešenie problému akú hodnotu treba brat' do úvahy pri výpočte hodnoty obmedzenia záväzku 25 zlatých frankov v národnej mene. Preto bol prijatý Protokol v roku 1978 v Ženeve s jediným účelom, nahradit’ zlatý frank novou jednotku SDR definovanou IMF, čím sa zrušil problém s výpočtom hodnoty zlata pre zmluvné štáty Protokolu. Podl'a protokolu je dopravca povinný odškodnit' vlastníka prepravovaného tovaru vo výške 8,33 SDR za každý kilogram poškodeného, zničeného alebo strateného tovaru (Radionov, 2016). Konkrétna hodnota závisí od výmenného kurzu SDR a €. Jeho hodnota je založená na hodnotách 5 národných mien (americký dolár, euro, japonský jen, čínsky jüan a libra šterlinkov). Taká suma je krytá aj poistením zodpovednosti dopravcu. Ak je však v nákladnom liste CMR uvedený osobitný záujem na dodaní, v tomto prípade dopravca ručí do hodnoty osobitného záujmu, ktorý môže byt' nad limitom hranice stanoveným Protokolom CMR.

Ako už bolo uvedené 56 krajín sveta je členskými krajinami Dohovoru CMR. Pristúpenie k Protokolu týkajúceho sa Dohovoru CMR nie je automatické, nevyplýva z postavenia členského štátu Dohovoru CMR. V tomto prípade z 56 krajín 11 krajín k tomuto Protokolu nepristúpilo. Medzi krajinami, ktoré ho neprijali je aj jedna krajina EÚ a tou je Bulharsko. Na nasledujúcom obrázku 2 sú znázornené členské krajiny Protokolu k Dohovoru CMR a zoznam jednotlivých krajín je uvedený v tabul'ke 1. 


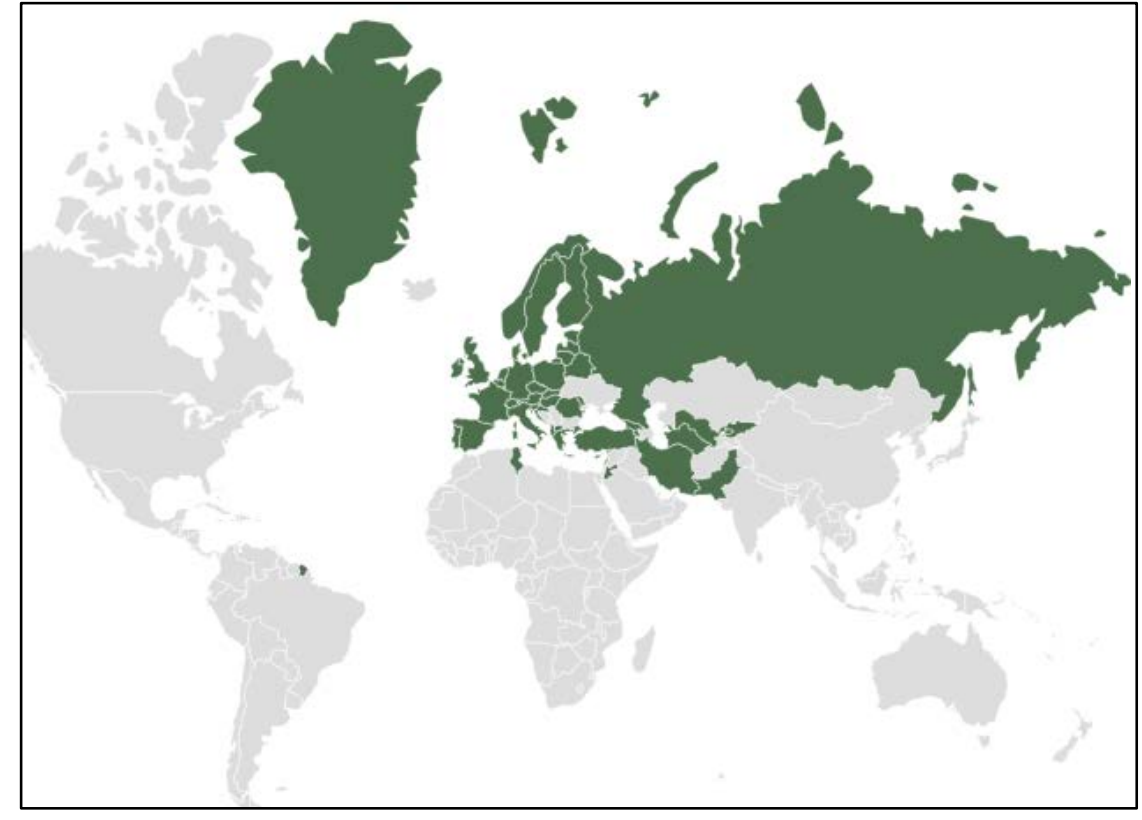

Obr. 2 Členské krajiny Protokolu; Zdroj: United Nations Treaty Collection

Ako už bolo spomínané nie všetky krajiny pristúpili k Protokolu, čoho následkom je rozdielne obmedzenie zodpovednosti dopravcu za poškodený, zničený alebo stratený tovar v jednotlivých krajinách. To má tiež vplyv na konkurencieschopnost' dopravcu. V Dohovore a Protokole je stanovená horná hranica obmedzenia zodpovednosti dopravcu. Hodnota zodpovednosti závisí od jednotky (GF alebo SDR), hrubej hmotnosti tovaru a aktuálneho výmenného kurzu. Prepočty zodpovednosti dopravcu za $1 \mathrm{~kg}$ hrubej hmotnosti tovaru sú uvedené vtabul'ke č.2. V prípade Dohovoru CMR sú uvedené dva výpočty zodpovednosti dopravcu. Prvý vychádza z poslednej definovanej umelej oficiálnej sadzby GF z roku 1978, druhý z aktuálnej vol'nej sadzby zlata. Výmenné kurzy a hodnota zlata je vyjadrená k dátumu 19.5.2020.

Tab. 2 Výpočet maximálnej zodpovednosti dopravcu za 1 kg hrubej hmotnosti tovaru; Zdroj: autor

\begin{tabular}{|c|c|c|}
\hline $\begin{array}{l}\text { Obmedzenie zodpovednosti } \\
\text { podl'a CMR } 1956\end{array}$ & $\begin{array}{l}\text { Obmedzenie zodpovednosti } \\
\text { podl'a CMR } 1956\end{array}$ & $\begin{array}{l}\text { Obmedzenie zodpovednosti } \\
\text { podl'a Protokolu CMR }\end{array}$ \\
\hline
\end{tabular}

\begin{tabular}{|c|c|c|}
\hline Obmedzujúca jednotka: GF & Obmedzujúca jednotka: GF & Obmedzujúca jednotka: SDR \\
\hline Obmedzenie: $25 \mathrm{GF}$ & Obmedzenie: 25 GF & Obmedzenie: 8,33 SDR \\
\hline $1 \mathrm{GF}=1,94149 \mathrm{USD}$ & $1 \mathrm{GF}=10 / 31$ g rýdzost' $900=0,323 \mathrm{~g}$ & $1 \mathrm{SDR}=1,259604 €$ \\
\hline $1 \mathrm{USD}=0,92 €$ & 1 g zlata $=46,28 € / g$ & $8,33 \mathrm{SDR}=8,33 \times 1,25960=10,49 €$ \\
\hline $1 \mathrm{GF}=1,94149 \times 0,92=1,79 €$ & $25 \mathrm{GF}=25 \times 0,323 \times 46,28=373,71 €$ & \\
\hline $25 \mathrm{GF}=25 \times 1,79=44,75 €$ & & \\
\hline $\begin{array}{l}\text { Maximálna zodpovednost' za } 1 \mathrm{~kg} \\
\qquad \mathbf{4 4 . 7 5 €}\end{array}$ & $\begin{array}{c}\text { Maximálna zodpovednost' za } 1 \mathrm{~kg} \\
\quad \mathbf{3 7 3 , 7 1 €}\end{array}$ & $\begin{array}{l}\text { Maximálna zodpovednost' za } 1 \mathrm{~kg} \\
\text { 10.49 EUR }\end{array}$ \\
\hline
\end{tabular}

Z tab. 2 vyplýva, že dopravcovia, ktorí si môžu uplatnit’ obmedzenie zodpovednosti podl'a Protokolu CMR, maximálne zodpovedajú do výšky 10,49 €/kg hrubej hmotnosti poškodeného, zničeného alebo strateného tovaru. Krajiny, kde obmedzujúcou jednotkou je GF a používajú na výpočet zodpovednosti poslednú umelo vytvorenú hodnotu GF, zodpovedajú do výšky 44,75€/kg hrubej hmotnosti tovaru. Ak by sa uvažovalo so súčasnou hodnotou zlata, dopravca by zodpovedal až do výšky $373,71 € /$ kg hrubej hmotnosti tovaru. 


\section{POISTENIE ZODPOVEDNOSTI CESTNÉHO DOPRAVCU}

Dopravca, ktorý vykonáva medzinárodnú cestnú dopravu zodpovedá za škodu na prepravovanom tovare podl'a Dohovoru CMR. Z tohto Dohovoru mu vyplýva povinné poistenie, známe pod názvom poistenie zodpovednosti cestného dopravcu. Účelom tohto poistenia je eliminovat' riziká dopravcu, ktoré môžu ohrozit' jeho podnikanie.

V súčasnej dobe je na poist'ovacom trhu široká ponuka poist'ovacích produktov, vzt'ahujúcich sa taktiež na krytie zodpovednosti cestného dopravcu. Aby sa dopravca v prípade spôsobenej škody na prepravovanej zásielke mohol na svoje poistenie spol'ahnút', musí pri jeho uzatváraní venovat' vel'kú pozornost' pri špecifikovaní potrieb spoločnosti (prepravovaný druh tovaru, typy prepravy,...) ako aj pri rozsahu krytia a podmienkach jednotlivých poist’ovni (Novák et al., 2018). Medzi dôležité špecifikácie rozsahu poisteného krytia patria:

- Limit poistného plnenia - maximálna horná hranica plnenia zo strany poist'ovne,

- Spoluúčast' - čiastka, ktorou sa dopravca podiel’a na škode (najčastejšie kombinácia \% a fixnej čiastky, napr. $10 \%$ minimálne $300 €$ ),

- Územná platnost' poistenia: Európa, Turecko, mimo štátov bývalého ZSSR s výnimkou Estónska, Lotyšska a Litvy,...

- Zoznam vozidiel: nákladné vozidla, t’ahače,

- Rozsah poistenia - základný rozsah poistného krytia a volitelné pripoistenia - vnútroštátna, medzinárodná alebo kabotážna preprava.

V nasledujúcej tabul'ke 3 sú uvedené ročné poistné sumy jednej z mnohých poist'ovni, ktoré závisia od poistného limitu a od počtu vozidiel v rámci uzatvorenia jednej poistnej zmluvy. Tieto poistné náklady sú platné pre základný rozsah poistného krytia a pre vol’ne ložený náklad.

Tab. 3 Poistné sumy pre základný rozsah poistného krytia; Zdroj: interné informácie poist’ovne

\begin{tabular}{lrrrrr}
\hline Počet vozidiel & \multicolumn{5}{c}{ Poistný limit } \\
\hline $\mathbf{1}$ & $200000,00 €$ & $300000,00 €$ & $400000,00 € 500000,00 €$ & $600000,00 €$ \\
$\mathbf{5}$ & $1292 €$ & $2112 €$ & $2239 €$ & $2365 €$ & $2490 €$ \\
$\mathbf{1 0}$ & $2069 €$ & $2958 €$ & $3134 €$ & $3310 €$ & $3487 €$ \\
$\mathbf{1 5}$ & $2908 €$ & $4225 €$ & $4478 €$ & $4730 €$ & $4982 €$ \\
\hline
\end{tabular}

Z tabul'ky3 vyplýva, že z hl'adiska nákladov na poistenie je najvhodnejšie vybavit' si poistnú zmluvu na čo najväčší počet vozidiel. Je potrebné však brat' do úvahy typ prepravy. Je zbytočné poist'ovat' všetky vozidlá, s čím sa zvyšujú náklady na poistenie, napr. na kabotážne prepravy, ak sa na to využívajú iba určíte vozidlá. Všeobecne platí, že poistný limit, na ktorý sa dopravca poist’uje, by mal zodpovedat' výpočtu, v ktorom užitočná hmotnost' vozidla predstavuje rozhodujúcu úlohu. Dopravca, ktorý prevádzkuje jazdnú súpravu s užitočnou hmotnost'ou 25 t, by mal zvolit' také poistenie svojej zodpovednosti, ktoré bude kryt' jeho zodpovednost' podl'a Protokolu CMR pri totálnom zničení zásielky, z toho vyplýva výška poistného by sa mala stanovit' podl'a nasledujúceho vzt'ahu: 8,33SDR/kg x $25000 \mathrm{~kg}=208250$ SDR za zásielku, čo pri výmennom kurze $(1,2596 €$ /SRD k 19.5.2020) predstavuje hodnotu $262312 €$. Bolo by zbytočné 
poist'ovat' sa na vyššiu sumu poistného limitu. Taktiež v prípade vozidiel s nižšou užitočnou hmotnost'ou je vhodné si prepočítat' maximálnu zodpovednost' dopravcu a podl'a toto si stanovit' poistný limit.

\section{VÝSLEDKY A DISKUSIA}

Poist'ovne vždy skúmajú, či dopravca nesie zodpovednost' za škodu, či boli splnené zo strany dopravcu a jeho subdodávatel'ov všetky povinnosti dané poistnou zmluvou a či sa na danú udalost' nevzt'ahuje niektorá z výluk uvedených v poistnej zmluve (Gnap a Skřivánek Kubíková, 2020). Poist'ovne dávajú obyčajne dopravcom za povinnost' hlásit' škody bezodkladne, poprípade s konkrétnym časovým limitom. Preto je vel'kou chybou nenahlásit' poist'ovni škodu ihned', ked' sa o nej dopravca dozvie a čakat' s jej oznámením až do doby, kedy poškodený uplatní voči dopravcovi reklamáciu. Ak sa jedná o poškodenie alebo zničenie zásielky, poist'ovne vel'mi často trvajú na možnosti zdokumentovat', čo najskôr aktuálny stav zásielky (rozsah škody), likvidátorom alebo nezávislým havarijným komisárom. Neumožnenie tohto úkonu zo strany dopravcu môže mat’ za následok výrazne krátenie poistného plnenia, prípadne aj úplné odmietnutie plnenia poist'ovňou.

Pri likvidácii škôd je nutné doložit’ nasledujúce doklady:

- objednávku prepravy,

- prepravné doklady (napr. nákladný list CMR, dodacie listy),

- zápis o škode medzi vodičom a príjemcom (ak nie je uvedená výhrada v príslušnom prepravnom doklade),

- protokol a konečné uznesenie polície (v prípade dopravných nehôd a škôd vzniknutých trestným činom),

- doklady preukazujúce hodnotu zásielky v dobe a mieste nakládky,

- doklady preukazujúce rozsah škody,

- fotodokumentácia rozsahu škody,

- vyjadrenie vodiča k okolnostiam škody.

Vzhl'adom na to, že pri likvidácii škôd je potrebné doložit' prepravný doklad, vo väčšine prípadov nákladný list CMR, jeho neutralizácia by mohla spôsobit' komplikácie pri riešení škodovej udalosti. Ak náhodou nebude existovat' nákladný list, dopravca sa nebude mat' čím preukázat'. Dopravca sa teda dostane do sporu s poist'ovňou, ked’že nebude môct' preukázat', že evidenčné čísla vozidiel v poistnej zmluve sa zhodujú s evidenčnými číslami v nákladnom liste CMR a poist'ovňa nemusí uhradit' škodu, ktorú zapríčinil dopravca. Poist'ovňa s ktorou sme spolupracovali uviedla, že ak sa pri preskúmaní škodovej udalosti zisti, že sa využila neutralizácia nákladného listu v rámci podvodu, čiže trestného činu, môže dôjst’ k zrušeniu poistného plnenia ale aj samotnej zmluvy zo strany poist'ovne. $V$ takom prípade by poist'ovňa nič neuhradila a za celu zodpovednost' dopravcu by dopravca zodpovedal sám.

Náklady, ktoré by musel dopravca znášat' sám sú vyjadrené na modelových príkladoch, ktoré sú uvedené v nasledujúcej tabul'ke 4. Do nákladov sú započítané aj náklady na poistnú zmluvu, ktoré musí dopravca uhradit', aby mohol vykonávat' medzinárodnú dopravu. Je to náklad, ktorý musí uhradit', ale to mu nezaručuje, že sa poist'ovňa bude spolupodiel'at' na škode. V týchto modelových príkladoch dopravca prepravuje tovar s celkovou hmotnost'ou $12 \mathrm{t}$. V každom príklade dochádza k poškodeniu celej zásielky, mení sa len hodnota tovaru. Poistné náklady sú stanovené pre jedno vozidlo s poistným limitom stanoveným podl'a hodnoty obmedzenia zodpovednosti. Hodnoty obmedzenia zodpovednosti dopravcu sú uvedené pod tabul'kou 4 . Všetky jednotky sú uvedené v $€$. 
Tab. 4 Škoda vzniknutá dopravcovi v prípade odmietnutia spoluúčasti poist'ovne, ; Zdroj: vlastné spracovanie

\begin{tabular}{cccccccc}
\hline $\begin{array}{c}\text { Hodnota } \\
\text { tovaru } \\
(\boldsymbol{(})\end{array}$ & $\begin{array}{c}\text { Obmedzenie } \\
\text { podl'a } \\
\text { Dohovoru } \\
(\boldsymbol{(})\end{array}$ & $\begin{array}{c}\text { Obmedzenie } \\
\text { podl'a } \\
\text { Protokolu } \\
(€)\end{array}$ & $\begin{array}{c}\text { Poistné } \\
\text { náklady } \\
\text { (Dohovor) } \\
(€)\end{array}$ & $\begin{array}{c}\text { Poistné } \\
\text { náklady } \\
\text { (Protokol) } \\
(\boldsymbol{(})\end{array}$ & $\begin{array}{c}\text { Celková } \\
\text { škoda pre } \\
\text { dopravcu } \\
\text { (Dohovor)(€) }\end{array}$ & $\begin{array}{c}\text { Celková } \\
\text { sooda pre } \\
\text { dopravcu } \\
\text { (Protokol)(€) }\end{array}$ & $\begin{array}{c}\text { Rozdiel } \\
\text { v nákladoch } \\
(€)\end{array}$ \\
\hline $\mathbf{1 0 0 ~ 0 0 0}$ & 100000 & 100000 & 2490 & 1292 & 102490 & 101292 & 1198 \\
$\mathbf{2 0 0 ~ 0 0 0}$ & 200000 & 125880 & 2490 & 1292 & 202490 & 127172 & 75318 \\
$\mathbf{3 0 0 ~ 0 0 0}$ & 300000 & 125880 & 2490 & 1292 & 302490 & 127172 & 175318 \\
$\mathbf{4 0 0 ~ 0 0 0}$ & 400000 & 125880 & 2490 & 1292 & 402490 & 127172 & 275318 \\
$\mathbf{5 0 0 ~ 0 0 0}$ & 500000 & 125880 & 2490 & 1292 & 502490 & 127172 & 375318 \\
$\mathbf{6 0 0 ~ 0 0 0}$ & 537000 & 125880 & 2490 & 1292 & 539490 & 127172 & 412318 \\
\hline
\end{tabular}

Zodpovednost' podl'a Dohovoru CMR sadzba $\mathrm{z}$ roku $1978=12000 \mathrm{x} 44,75=537000 €$ Zodpovednost' podl'a Dohovoru CMR aktuálna sadzba zlata $=12000 \times 373,71=4484520 €$ Zodpovednost' podl'a Protokolu CMR $=12000 \times 10,49=125880 €$

V prípade poškodenia tovaru s hodnotou $100000 €$ nedochádza k výraznému rozdielu v nákladoch. Rozdiel je spôsobený iba tým, že dopravca, ktorého zodpovednost' je obmedzená Dohovorom CMR by mal mat' uzatvorenú poistnú zmluvu s vyšším poistným limitom, s čim sú spojené aj vyššie náklady na poistenie. Pri tovare s hodnotou $200000 €$ už dochádza k výraznejšiemu rozdielu. Tento rozdiel je spôsobený okrem rozdielu v poistných nákladov, najme ohraničeným zodpovednosti dopravcu podla Protokolu. Čím je hodnota tovaru vyššia tým je tento rozdiel v nákladoch vyšší. Z týchto príkladov vyplýva, že dopravcovi (ktorý sa riadi Protokolom) vznikne maximálne škoda vo výške $127172 €$, pričom dopravcovi ktorý sa riadi ustanoveniami Dohovoru môže vzniknút' škoda až $539490 €$, v závislosti od hodnoty zásielky. V prípade ak by sa uvažovalo s aktuálnou hodnotou zlata, zodpovednost' dopravcu by bola minimálne obmedzená, ak vôbec (iba v prípade vel'mi drahého tovaru).

Aj ked' Protokol, v niektorých krajinách iba Dohovor, obmedzuje zodpovednost' dopravcu za škodu na zásielke, dopravca je povinný uhradit' vzniknutú škodu aj ked' poist’ovňa odmietne spoluúčast' na základe porušenia poistných podmienok. Náhrada škody bez spoluúčasti poist'ovne predstavuje pre dopravcu výraznú nákladovú položku, ktorá môže predstavovat' v niektorých prípadoch aj katastrofálne následky pre dopravnú spoločnost'. Z toho dôvodu je možné pokladat' dopad na poistenie zodpovednosti za jedno z najzávažnejších rizík, ktoré by si mal dopravca uvedomit', ked’ príjme príkaz na neutralizáciu prepravných dokladov. Tieto závažnosti by si mali uvedomit' najmä dopravcovia (napr. Bulharskí), ktorý sa riadia ustanoveniami Dohovoru CMR, im hrozí z pohl'adu vzniknutých nákladov ovel’a väčšie riziko.

\section{ZÁVER}

Dohovor CMR, ktorý upravuje prepravnú zmluvu pri medzinárodnej cestnej nákladnej doprave patrí dnes k najdôležitejším nástrojom rozdelenia zodpovednosti medzi dopravcu a objednávatel'a prepravy. Prijatím Dohovoru sa dopravcom obmedzila zodpovednost', pričom toto obmedzenie bolo postavené na jednotke GF, ktorej hodnota bola závislá od pevnej hodnoty zlata. Neskôr, kvôli problémom s dvoma hodnotami zlata bol prijatý Protokol, ktorý mal vyriešit' tento problém. Hodnota zodpovednosti už nebola viac závislá od hodnoty zlata ale od jednotky SDR ktorej hodnota závisí v súčasnosti od 5 národných mien. Vzhl'adom na to, že pristúpenie k Protokolu nie je automatické, existujú krajiny ktoré prijali Dohovor CMR ale už 
neprijali Protokol. V súčasnosti 1/5 zmluvných strán Dohovoru nepristúpila k Protokolu. Je dôležité poznamenat', že všetky krajiny EU sú zmluvnými stranami okrem Bulharska. To je obzvlášt' dôležite vzhl'adom na skutočnost', že niektoré z hlavných koridorov transeurópskej dopravnej siete prechádzajú touto krajinu a takéto neprimerané vystavenie zodpovednosti môže mat' vplyv na obchodné záujmy všetkých zúčastnených strán na zmluve o medzinárodnej preprave tovaru. Vzhl'adom na to, že táto krajina nepristúpila je tu vyššia úroveň zodpovednosti pre dopravcu ako v ostatných členských krajinách EU. To mení aj podmienky poistenia zodpovednosti a má to vplyv aj na náklady za poistenie zodpovednosti.

V súvislosti s neutralizáciou nákladného listu CMR hrozí vel'ké riziko dopravcovi v prípade ak dôjde k poškodeniu tovaru, kde pri preskúmaní škodovej udalosti sa zisti podvod. Ak sa vykoná neutralizácia prepravných dokladov, môže to spôsobit' komplikácie pri riešení škodovej udalosti. Ak by náhodou neexistoval nákladný list, dopravca sa nebude mat' čim preukázat'. Dopravca sa môže dostat' do sporu s poist'ovňou, a poist'ovňa môže zrušit' s dopravcom poistné plnenie a aj samotnú poistnú zmluvu. Dopravca bude musiet' uhradit' škodu sám.

\section{Pod'akovanie}

Tento dokument bol vypracovaný na podporu projektu: VEGA č. 1/0245/20 Poliak: Identifikácia dopadu zmeny právnych predpisov $\mathrm{v}$ oblasti dopravy na konkurencieschopnost' dopravcov a bezpečnost' prepravy.

\section{Literatura}

Ahmadi, R., Iravani, F. a Mamani, H. 2017. Supply Chain Coordination in the Presence of Gray Markets and Strategic Consumers. Production and operations management, 26(2), s. 252-272.

<https://doi.org/10.1111/poms.12635>

Ahmadi, R., Yang, B. R. 2000. Parallel imports: Challenges from unauthorized distribution channels. Marketing science, 19(3), s. 279-294. DOI: 10.1287/mksc.19.3.279.11799.

Bonnet, J.C. 2016. CMR - International Convention of Geneva relating to the Contract for the International carriage of goods by Road 19 May 1956. Uniform Law Review, 21(4), s. 418-420. D0I: 10.1093/ulr/unw052

Denes, A. 2018. Considerations on the contract for the international carriage of goods by road. Revista De La Facultad De Derecho, s. 253-285. DOI: 10.22187/rfd2018n44a9

Dohovor o prepravnej zmluve $\mathrm{v}$ medzinárodnej cestnej nákladnej doprave. Dostupné na internete: <https://www.cesmad.sk/kategoria/26-legislativa/1712-dohovor-o-prepravnej-\%20zmluve-\%20vmedzinarodnej-cestnej-nakladnej-doprave-cmr->

Gnap, J., Skřivánek Kubíková, S. 2020. Possible effects of lacking parking areas for road freight transport on logistics and transport safety. Transportation Research Procedia, 44, s. 53-60. https://doi.org/10.1016/j.trpro.2020.02.009

Interné informácie poist’ovne

Lamont-Black, S. 2016. The UK Supreme Court on jurisdiction over successive CMR Convention carriers and European Union rules. Uniform Law Review, 21(4), s. 487-509. DOI: 10.1093/ulr/unw041

Lorenc, A., Kuznar, M. 2018. An Intelligent System to Predict Risk and Costs of Cargo Thefts in Road Transport. International journal of engineering and technology innovation, 8(4), s. 284-293.

Mukherjee, A., Zhao, L. 2012. Profitable parallel trade in unionized. Journal of Economics, 107(3), s. 267276. DOI: $10.1007 / \mathrm{s} 00712-012-0267-7$

Novák, R. a kol. 2018. Mezinárodní silniční nákladní přeprava a zasílatelství, Praha: Nakladatelství C. H. Beck, 342 s. 
Poliak, M., Tomicová, J., Jaśkiewicz, M. 2020. Identification the risks associated with the neutralization of the CMR consignment note. Transportation Research Procedia, 44, s. 23-29. DOI: 10.1016/j.trpro.2020.02.004

Protokol k Dohovoru o prepravnej zmluve v medzinárodnej cestnej nákladnej doprave. Dostupné na internete: https://www.noveaspi.sk/products/lawText/1/67138/1/2/oznamenie-c-163-2008-zz-opodpisani-protokolu-k-dohovoru-o-prepravnej-zmluve-v-medzinarodnej-cestnej-nakladnej-dopravecmr/oznamenie-c-163-2008-zz-o-podpisani-protokolu-k-dohovoru-o-prepravnej-zmluve-vmedzinarodnej-cestnej-nakladnej-doprave-cmr

Quigley, I. 2006. Freight Carrier`s Liability under the CMR convention 1956. Acta Oeconomica Pragensia. 2006 (4), s. 41-45.

Radionov, N. 2016. Limitation of liability right in road freight carriage in Croatia: an extinct institute. Uniform Law Review, s. 457-468. DOI: 10.1093/ulr/unw035

Sker, T. 2003. Analysis of Road Carriers Liability for Robbery of Cargo According to CMR Convention. Promet- Traffic- Traffico, s. 371-374.

United Nations Treaty Collection. [Online]. Dostupné z: https://treaties.un.org/pages/ViewDetails.aspx?src=TREATY\&mtdsg no=XI-B-11a\&chapter=11\&clang= en [cit: 2020-05-23].

Verheyen, W. 2016. National judges as gatekeepers to the CMR Convention. Uniform Law Review, 21(4), s. 441-456. <https://doi.org/10.1093/ulr/unw039> 